\title{
MAKNA DAN NILAI SPIRITUAL MUSIK HADRAH PADA KOMUNITAS HADRAH EL- MAQOSHID
}

\author{
Arum Mei Nursyahida dan Amika Wardana \\ Pendidikan Sosiologi Fakultas IImu Sosial Universitas Negeri Yogyakarta \\ Email : arummei98@gmail.com
}

\begin{abstract}
Abstrak
Penelitian ini bertujuan untuk mengetahui makna dan nilai spiritual yang terkandung dalam musik hadrah pada komunitas hadrah El-Maqoshid, serta melihat bagaimana komodifikasi hadrah merubah makna dan nilai spiritual pada komunitas hadrah El-Maqoshid. Penelitian ini menggunakan metode penelitian kualitatif deskriptif dengan teknik pengumpulan data menggunakan wawancara, observasi, dan dokumentasi. Dalam penelitian ini, informan penelitian ditentukan menggunakan teknik purposive sampling. Hasil penelitian ini menunjukkan bahwa makna dan nilai spiritual musik hadrah yang ada pada komunitas hadrah El-Maqoshid tidak mengalami perubahan akibat terjadinya komodifikasi. Makna dan nilai spiritual tersebut meliputi ritual pemujaan, sarana bersyiar dan berdakwah, penyampaian doa, kekuatan jiwa, sarana hiburan, dan eksistensi religius. Tidak dapat dipungkiri dan secara tidak sadar, komunitas hadrah El-Maqoshid memang melalukan komodifikasi agama khususnya pada musik hadrah. Namun, yang perlu digarisbawahi bahwa komodifikasi tersebut dilakukan untuk kepentingan dan kesejahteraan anggota El-Maqoshid. Hampir semua keberlangsungan kegiatan El-Maqoshid didukung oleh proses komodifikasi tersebut.
\end{abstract}

Kata kunci : hadrah, makna, nilai spiritual, komodifikasi

Abstract

This study aims to determine the meaning and spiritual value embodied in the hadrah El-Maqoshid community, as well as see how the commodification hadrah changes the meaning and spiritual value of the hadrah el-Maqoshid community. This research uses a qualitative method of descriptive research with data collection techniques using interviews, observations, and documentation. In this study, research informant was determined using purposive sampling technique. The results showed that the meaning and spiritual value of the music in the hadrah of El-Maqoshid was not changed due to commodification. These meanings and spiritual values include ritual adoration, means of worship and preaching, the delivery of prayers, the soul strength, the means of entertainment, and religious existence. Unable to be denied and unconsciously, El-Maqoshid's hadrah community is a commodification of religion, especially in the musical hadrah. However, it should be highlighted that the commodification is done for the benefit and welfare of the members of El-Maqoshid. Almost all the sustainability of the El-Maqoshid activity is supported by the process of commodification.

Keywords : hadrah, mean, spiritual value, commodification

\section{Pendahuluan}

Hadirnya musik di tengah-tengah masyarakat tidak lain memiliki tujuan yang berbeda di setiap jenis musiknya. Banyak masyarakat yang memanfaatkan musik sebagai media relaksasi, ada juga musik yang digunakan sebagai hiburan semata, serta banyak juga masyarakat yang memanfatkan musik sebagai ritual maupun dakwah. Fungsi musik dapat dilihat dari keberadaan musik secara fungsional (Rahman, 2018:2). Fungsi musik ini di antaranya meliputi fungsi musik sebagai sarana upacara, sarana komunikasi, dan pengiring tarian. 
Dalam sebuah pondok pesantren yang dikemukakan oleh Asep Solikin (2015:22) menerapkan musik khususnya musik Qosidah Burdah sebagai media penyeimbang antara domain kognisi, afeksi, dan psikomotor. Bahkan pengajian di pondok pesantren tersebut yang dilengkapi dengan musikalisasi dianggap efektif dalam proses internalisasi nilai.

Musik Islami menjadi salah satu musik yang berkembang dan diakui oleh kalangan masyarakat. Masyarakat meyakini bahwa musik Islami merupakan musik yang mengandung arti pemujaan terhadap Allah Swt. Apa yang ada di dalam musik Islami tidak lain mengandung lagu-lagu yang erat kaitannya dengan ajaran-ajaran Islam, terlebih lagi musik ini menjadi satu bentuk pertunjukkan seni musik yang menunjukkan ciri khas bagi umat Islam. Menurut sufistik dan para filosof musik Islam justru menjadi salah satu media penting untuk mendekatkan diri kepada Allah.

Yusuf Al-Qaradhawy (Afianto, 2017:2) memberikan tiga syarat yang ketat mengenai musik Islam, di antaranya; (1) Tema atau isi nyanyian harus sesuai dengan ajaran dan adab Islam, (2) Mempertimbangkan penampilan penyanyi, (3) Tidak berlebihan atau melampaui batas. Dari situlah jelas bahwa fungsi dan tujuan dari musik Islami itu sendiri adalah untuk menghormati dan mendekatkan diri kepada Allah dengan sopan santun sebaik mungkin.
Musik hadrah merupakan salah satu kesenian Islam yang saat itu digunakan oleh Walisongo sebagai media berdakwah. Hingga pada saat ini, musik hadrah telah dikenal dan berkembang pesat di masyarakat yang terkenal akan nuansa Islaminya. Kesenian hadrah sendiri sudah populer di kalangan majelis taklim yang dipimpim oleh beberapa ulama, kyai, habib yang kemudian menyebar di kalangan masyarakat. Namun, pada dasarnya kesenian hadrah sudah ada sejak abad ke6. Hal ini dibuktikan bahwa pada masa itu, masyarakat Madinah menggunakan hadrah sebagai musik pengiring dalam acara penyambutan atas kedatangan Nabi Muhammad Saw yang hijrah dari Mekkah (Nirwanto, 2015:39).

Musik hadrah yang awalnya digunakan sebagai media dakwah maupun sarana pemujaan kepada Allah Swt dan Nabi Muhammad Saw oleh masayarakat Islam, telah berubah bentuknya menjadi musik pertunjukkan yang populer dan berfungsi sebagai hiburan. Fenomena ini terjadi dengan adanya penggunaan instrument modern dan juga lebih digunakan untuk acara-acara tertentu meskipun bukan acara keagamaan. Padahal, sejatinya perkembangan religiusitas seseorang dapat dikembangkan melalui sentuhan-sentuhan makna yang bisa menghidupkan spiritual dan nuansa kebatinan dalam beragama. 
Menurut Pargament (Fridayanti, 2015:204) spiritualitas dipandang sebagai salah satu hal yang sangat penting, hal ini dikarenakan melalui spiritualitas terdapat sebuah motivasi (pencarian) terhadap Tuhan. Terbentuknya spiritualitas juga akan menciptakan sebuah komitmen dari apa yang manusia pahami. Oleh karena itu, ketika spiritualitas telah bergeser atau bahkan tidak ada nilai spiritualitas di dalam sebuah simbol, tidak ada pula keyakinan dan ketentraman manusia. Sama halnya dengan musik hadrah yang berkembang saat ini, yang lebih mengutamakan nilai estetik (hiburan). Kurangnya nilai spiritualitas yang dipertahankan membuat musik hadrah kehilangan maknanya yaitu ritual mengenal lebih dekat agama, nabi, dan Tuhan.

Kondisi di mana telah terjadi adanya pergeseran makna dari simbol-simbol yang diberikan oleh agama dapat dikatakan sebagai komodifikasi agama. Hal ini sejalan dengan apa yang telah dikatakan oleh Theodore Adorno dan Horkheimer sebagaimana yang dikutip Agger (2006:57). Kedua tokoh aliran sosiologi kritis tersebut melihat bahwa agama dan budaya di era kapital telah menjelma sebagai sebuah komoditas. Artinya, suatu fenomena agama dan budaya akan diproduksi secara terusmenerus, lengkap dengan berbagai macam modifikasi guna memperoleh keuntungan. Jika hal ini terus-menerus terjadi tanpa melihat makna dan nilai spiritual yang terkandung di dalamnya maka akan menggeser makna sambutan, puji-pujian, dan penghormatan serta kekaguman yang mendalam kepada Nabi dan pengikutpengikutnya yang senantiasa menyertai perjalanan-Nya (Niaga, 2006:2).

Belakangan ini ada kecenderungan terjadinya pergeseran cara pandang terhadap agama, dimana agama telah dipandang sebagai sebuah komoditas, sehingga sadar ataupun tidak agama yang sarat dengan fungsi-fungsi religiusitas telah mengalami proses komodifikasi. Oleh karena itu menarik untuk menelusuri adanya kecenderungan bagi berkembangnya fenomena komodifikasi agama terebut melalui pemberian makna dan nilai spiritual musik hadrah pada komunitas hadrah ElMaqoshid.

Potret komunitas hadrah El-maqoshid yang berada di Yogyakarta ini terusmenerus berkembang dan menjadi salah satu daya hiburan, sehingga makna-makna awal dari hadrah yang sarat dengan nuansa religius semakin bergeser pada hingarbingar berbagai kegiatan atau acara, tidak hanya acara keagamaan. Komunitas Hadrah El-Maqoshid merupakan salah satu komunitas yang menekuni kesenian hadrah sebagai bentuk pelestarian kesenian Islami di Yogyakarta.

\section{Metode}

Penelitian ini termasuk ke dalam peneitian kualitatif deskriptif. Alasan 
digunakannya jenis penelitian kualitatif karena penulis ingin mengeksplor atau menjelaskan sebuah fenomena yang tidak dapat dikuantitatifkan, artinya data-data yang akan diperoleh nantinya bukanlah suatu angka melainkan berupa penjelasanpenjelasan atas fenomena tersebut. Oleh karena itu, penulis akan menggunakan jenis penelitian kualitatif deskriptif, dimana akan dibahas dan dijelaskan secara detail terkait makna dan nilai spiritual musik hadrah khususnya pada komunitas hadrah ElMaqoshid. Serta menjelaskan komodifikasi yang terjadi, sehingga menggeser makna dan nilai spiritual musik hadrah pada komunitas hadrah El-Maqoshid tersebut. Penelitian ini dilakukan pada bulan Januari hingga Februari 2020 pada komunitas hadrah El-Maqoshid tepatnya di Samirono, Caturtunggal VI, Nomor 80, Depok, Sleman, Yogyakarta. Subjek dalam penelitian ini adalah anggota, pengurus, serta alumni komunitas hadrah El-Maqoshid. Teknik pengambilan sampel yang digunakan dalam penelitian ini yaitu purposive sampling dengan kriteria (1) ikut dalam anggota, alumni, maupun pengurus Komunitas Hadrah El-Maqoshid KMNU UNY sekurangkurangnya satu tahun (2) Pernah maupun sering mensiarkan musik Hadrah di berbagai acara dan tempat (3) Mengetahui makna musik hadrah (4) Sering mengkonsumsi musik hadrah dalam kesehariannya.
Data dalam penelitian ini menggunakan data primer yang diperoleh dari hasil wawancara yang bersumber dari responden yaitu anggota, pengurus, maupun alumni komunitas hadrah ElMaqoshid, serta hasil observasi pada kegiatan komunitas hadrah El-maqoshid. Sedangkan data sekunder yang digunakan yaitu berupa dokumentasi, baik itu berupa arsip, buku, jurnal, maupun studi kepustakaan. Penulis menggunakan teknik triangulasi sumber. Penulis akan menanyakan kembali mengenai data yang telah diperoleh melalui wawancara dari informan kepada penulis. Kemudian setelah data diperoleh melalui wawancara, penulis melakukan analisis data dengan kajian kepustakaan yang telah ditentukan sebelumnya. Penulis juga membandingkan hasil wawancara tersebut dengan kenyataan ketika mereka melakukan kegiatan di beberapa kegiatan. Penelitian ini menggunakan teknik analisis data kualitatif deskriptif yang dikemukakan oleh Miles dan Huberman (2009) yang dilakukan dalam empat tahap, diantaranya, pengumpulan data, reduksi data, penyajian data, dan penarikan kesimpulan

\section{Hasil dan Pembahasan}

\section{Komodifikasi Musik Hadrah El- Maqoshid}

Komunitas hadrah El-Maqoshid telah berdiri sejak tahun 2008 dan mengalami perkembangan yang cukup pesat. Memiliki 
nama di masyarakat umum merupakan salah satu prestasi yang patut dibanggakan. Banyaknya undangan yang didapat membuat pendapatan komunitas ElMaqoshid ini semakin bertambah. Terdapat sistem feedback atau disebut dengan bisyaroh yang cukup menguntungkan bagi komunitas ini. Hal ini sejalan dengan pengertian komodifikasi agama yang merupakan usaha secara sadar mengubah simbol dan institusi agama menjadi komoditas yang bisa dipasarkan dan layak konsumsi.

Bentuk-bentuk komodifikasi yang ada pada komunitas hadrah El-Maqoshid diantaranya melalui eksistensi yang selalu digencarkan. Media sosial menjadi sasaran utama bagi komunitas ini, mengunggah foto maupun video ketika mereka latihan atau tampil merupakan salah satu cara yang dilakukan. Update terkait lagu-lagu sholawat juga terus dilakukan, kemudian juga melakukan rekaman yang dijadikan sebagai konten youtube. Melatih grup hadrah juga merupakan salah satu kegiatan El-Maqoshid yang mendapatkan keuntungan. Serta yang paling sering dilakukan yaitu menghadiri dan tampil di berbagai acara, tidak hanya di acara keagamaan.

Tidak dapat dipungkiri dan secara tidak langsung komunitas hadrah ElMaqoshid telah melakukan praktik komodifikasi agama melalui musik hadrah tersebut. Namun perlu digarisbawahi bahwa komunitas ini melakukan komodifikasi demi keberlangsungan dan kesejahteraan para anggotanya. Feedback atau bisyaroh bukan tujuan utama mereka bermain musik hadrah. Hal ini dibuktikan dengan tidak pernahnya mematok harga pasaran. Selain itu, banyak sedikitnya bisyaroh yang didapatkan setelah tampil di berbagai acara sangat tidak mempengaruhi banyak sedikitnya pemain yang mau ikut untuk hadrah..

Meskipun mereka memiliki jam tampil yang sudah cukup banyak, mereka tetap beracuan pada apa yang disebutkan oleh Faqih (1998:127) bahwa Islam memiliki garis yang tegas dan jelas tentang etika produksi dan sekaligus etika konsumsi. Jadi tidak semua simbol dan nilai dapat dijadikan sebagai komditas yang layak diperjual belikan. Seringnya tampil di berbagai acara tanpa melihat besar kecilnya feedback yang didapatkan merupakan tradisi yang telah diterapkan oleh sesepuh atau pendiri komunitas hadrah El-Maqoshid. Hal ini tidak membuat musik hadroh berubah, kesenian musik hadrah masih digunakan seperti tujuan awal yaitu untuk mensyiarkan sholawat Nabi Muhammad Saw kepada masyarakat umum, bukan sebagai alat untuk mendapatkan sebuah profit.

Berikut merupakan cara pengurus komunitas hadrah El-Maqoshid dalam menggunakan feedback yang telah didapatkan setelah mereka tampil di berbagai acara : 
a. Mensejahterakan Personil Hadrah

El-Maqoshid merupakan salah satu komunitas hadrah yang telah memiliki jam tampil yang cukup padat, hampir setiap minggu mereka mendapatkan undangan untuk tampil di berbagai acara. El-Maqoshid memiliki jumlah anggota yang cukup banyak, sehingga tidak ada alasan untuk menolak undangan tersebut hanya karena kekurangan personil.

Setiap selesai tampil komunitas hadrah El-Maqoshid selalu mendapatkan feedback di saat mereka selesai tampil di berbagai acara baik itu berupa uang maupun konsumsi. Uang yang didapatkan tersebut akan digunakan untuk mensejahterakan para pemain atau anggota. El-Maqoshid akan menanggung biaya transportasi dan konsumsi bagi semua pemain yang tampil saat itu.

\section{b. Kepentingan Program Kerja}

Layaknya organisasi-organisasi lain yang memiliki program kerja, El-Maqoshid memiliki program kerja yang harus dilaksanakan selama satu periode kepengurusan, di antaranya latihan rutin hadrah, tari sufi, dan MTQ; open recruitment dan temu perdana; harlah El-Maqashid; perbaikan dan pengadaan alat; pengadaan seragam.

Kelima program kerja tersebut merupakan program kerja yang sama-sama membutuhkan biaya. Dari berbagai pernyataan sebelumnya, dapat dikatakan bahwa adanya feedback yang didapatkan setelah tampil di berbagai acara sangat mempengaruhi keberlangsungan semua kegiatan yang diadakan oleh komunitas hadrah El-Maqoshid. Uang atau feedback akan masuk ke kas El-Maqoshid yang dikelola langsung oleh pengurus. Dalam pembagian uang untuk setiap program kerja didasari atas besar kecilnya program kerja tersebut.

\section{Makna dan Nilai Spiritual Musik Hadrah pada Komunitas Hadrah El- Maqoshid}

Wuthnow (Turner, 2013:466) mendefinisikan spiritualitas sebagai kondisi terhubung dengan tatanan realita yang ilahi, adikrodati atau transenden atau sebaliknya, sebagai pemahaman atau kesadaran akan suprarealita yang melampaui kehidupan sebagaimana dialami sehari-hari. Minat pada spiritualitas lazimnya dinyatakan dalam bentuk kepercayaan pada Tuhan dan makhluk ilahi lainnya. Seorang individu yang berbicara tentang spiritualitas sesungguhnya secara aktif memilah dan memilih sesuatu yang dirasakan cocok dengan hidupnya (Larasati, 2015:12). Kebanyakan dari anggota maupun pengurus komunitas hadrah El-Maqoshid memilih gabung dengan El-Maqoshid karena mereka satu pemahaman.

Praktik komodifikasi yang dilakukan oleh komunitas hadrah El-Maqoshid tidak membuat mereka keluar dari tujuan bersholawat. Komunitas ini masih mempertahankan makna dan nilai spiritual 
yang terkandung dalam musik hadrah. Secara umum, makna dan nilai spiritual musik hadrah pada komunitas hadrah ElMaqoshid yang berkembang saat ini sebagai berikut :

a. Ritual Pemujaan

Musik hadrah merupakan salah satu kesenian Islam yang menjunjung tinggi sholawat. Semua yang berkaitan dengan kisah perjalanan dan perjuangan Nabi Muhammad Saw dituangkan dalam syair sholawat yang biasanya dibawakan oleh musik hadrah. Selain kisah perjalanan Nabi Muhammad Saw, dalam sholawat yang dikemas dalam musik hadrah juga dapat berfungsi sebagai sarana berdzikir, sebagai manifestasi dan wujud syukur kepada Allah Swt atas nikmat yang telah diberikan kepada hamba-hambaNya.

Kecintaan mereka kepada Nabi Muhammad Saw yang tidak lagi dapat diukur membuat mereka tidak ada hentinya berkarya melalui musik hadrah. Hal ini selaras dengan nilai spiritualitas yang ada pada musik hadrah, bahwasannya musik hadrah dapat mendekatkan kita dengan Allah Swt dan Nabi Muhammad Saw.

\section{b. Bersyiar dan Berdakwah}

Lagu-lagu yang dibawakan oleh komunitas hadrah El-Maqoshid khususnya memiliki arti dan ajaran-ajaran mengenai Islam. Dengan sesama umat Islam, kita wajib saling mengingatkan terkait apa itu Islam, bagaimana cara kita memuja Tuhan dan Nabi, bagaimana kita berperilaku dengan sesama, dan hal apa saja yang boleh maupun tidak boleh dilakukan. Semua itu terdapat dalam syair hadrah yang dibawakan oleh komunitas hadrah ElMaqoshid. Oleh karena itu, tujuan dari komunitas hadrah El-Maqoshid ini adalah berdakwah dan mensyiarkan sholawat kepada Kanjeng Nabi Muhammad Saw.

c. Penyampai Doa

Melakukan ritual berdoa juga merupakan aspek spiritualitas berupa aspek perilaku. Komunitas hadrah El-Maqoshid memainkan musik hadrah ini seolah-olah sebagai usaha untuk berdoa kepada Allah Swt dan Nabi Muhammad Saw, dan ini jelas dapat dilihat secara kasat mata. Seperti yang dikatakan oleh Anandarajah\&Hight (Prasetyo, 2016:20) bahwa aspek perilaku lebih melibatkan cara seseorang melakukan sesuatu yang terlihat seacara kasat mata yang merupakan manifestasi daro keyakinan spiritual seseorang dan kondisi spiritual dalam diri orang tersebut. Hal ini menggambarkan terjadinya praktik keagamaan yang dilakukan oleh komunitas hadrah El-Maqoshid melalui musik hadrah.

Pada intinya, telah terjadi proses penyerahan diri manusia kepada Tuhan, dalam keyakinannya manusia tergantung pada Tuhan, Tuhan merupakan keselamatan yang sejati bagi manusia. Manusia dengan kekuatannya sendiri tidak mampu untuk memperoleh keselamatan, maka manusia melakukan penyerahan diri kepada Tuhan. 
Komunitas hadrah El-Maqoshid mempercayai bahwa dengan melantunkan sholawat kepada Kanjeng Nabi Muhammad Saw mereka akan mendapatkan syafaat sebagai penolong di alam akhirat nanti. Mereka juga mempercayai bahwa apabila mereka dekat dengan Kanjeng Nabi Muhammad Saw maka secara otomatis mereka juga dekat dengan Allah Swt.

\section{d. Kekuatan Jiwa}

Terdapat tiga aspek spiritualitas yang dikemukakan oleh Prasetyo (2016:19), yaitu aspek kognitif, aspek pengalaman, dan aspek perilaku. Menurut ketiga aspek tersebut, spiritualitas yang dimiliki oleh komunitas hadrah El-Maqoshid pada saat ini sudah berada pada aspek pengalaman. Meskipun tidak dapat diamati secara kasat mata, aspek ini dapat diketahui melalui data wawancara yang telah dilakukan. Dari narasumber yang terlibat dalam penelitian ini menyebutkan bahwa mereka menemukan sebuah kedamaian hati dan juga menumbuhkan rasa cintanya kepada Allah Swt dan Nabi Muhammad Saw melalui musik hadrah yang mereka nikmati atau mainkan sehari-hari. Pada hahikatnya, aspek pengalaman melibatkan perasaan adanya harapan, cinta, hubungan, kedamaian hati, kenyamanan, dan dukungan.

Flanagan (Turner, 2013:466) mengungkapkan bahwa spiritualitas merujuk pada aspek niscaya dari makna hakiki sebagai manusia. Dilihat dari semangat para anggota komunitas hadrah El-Maqoshid menunjukkan bahwa mereka telah menemukan ambisi, penyemangat, dan dorongan untuk membawa dirinya lebih dekat dengan Allah Swt dan juga Nabi Muhammad Saw. Dari situlah karena merasa sangat dekat dengan tuhan dan nabinya, ia akan merasa tenang dan merasa bahwa mereka akan dilindungi dimana pun dan kapan pun.

e. Hiburan

Komunitas hadrah El-Maqoshid merupakan salah satu komunitas yang berkonsentrasi di bidang musik khususnya musih hadrah. Sama halnya dengan musik yang lainnya, musik hadrah yang berkembang saat ini juga dapat digunakan sebagai hiburan di acara-acara tertentu. ElMaqoshid sering diminta untuk menghibur di beberapa acara seperti acara pernikahan, khitanan, acara seminar, peresmian masjid atau mushola, dan lain-lain.

Selain untuk memberikan doa, ucapan selamat kepada yang memiliki acara, juga memiliki nilai pertunjukkan lagu untuk dinikmati. Meskipun berkonsentrasi pada musik bernuansa Islam, hadrah ini tetap menggunakan alat musik yang pastinya akan lebih menarik penonton untuk menikmatinya.

f. Eksistensi Religi

Secara tidak sadar, pemberian makna pada musik hadrah yang ada pada komunitas hadrah El-Maqoshid ini telah mengarah pada pemanfaatan musik hadrah 
sebagai eksistensi kelompok. Musik hadrah tidak lagi hanya dimaknai sebagai ritual pemujaan yang sangat erat kaitannya dengan Allah Swt dan nabi Muhammad Saw, tetapi juga telah muncul pemaknaan baru berupa alat eksistensi atau dapat juga dikatakan sebagai eksistensi religius. Eksistensi ini mengarah pada penggunaan simbol-simbol agama yang dalam hal ini berupa musik hadrah untuk mempertahankan keberadaan suatu kelompok dalam masyarakat.

Komunitas hadrah El-Maqoshid melakukan berbagai cara guna mempertahankan dan menambah eksistensi dirinya. Adapun cara yang dilakukan di antaranya, informasi mulut ke mulut, penyebaran pamflet, dan melalui media sosial.

\section{Spiritualitas dan Religiusitas}

\section{Komunitas Hadrah El-Maqoshid}

Pargament (Fridayanti, 2015:204) merumuskan pengertian religiusitas dan spiritualitas, di mana religiusitas didefinisikan sebagai "search for significance in ways related to the sacred", sedangkan spiritualitas didefinisikan sebagai "spirituality as a search for the sacred". Artinya, terdapat unsur kesamaan dalam agama dan spiritualitas yaitu dipandang sebagai motivasi (pencarian) terdapat Tuhan. Dalam hal ini titik persamaan religiusitas dan spiritualitas adalah pencarian terhadap yang maha Suci. Begitu pula dengan Sulmasy (Prasetyo,
2016:20) masing-masing agama dapat menjawab berbagai macam pertanyaan spiritual dan mampu mengembangkan keyakinan yang spesifik, memberikan pencerahan dan praktik spiritual.

Kesenian musik hadrah yang erat kaitannya dengan ritual keagamaan khususnya agama Islam menjadi salah satu cara seseorang untuk mengenal lebih dekat dengan agamanya. Komunitas hadrah ElMaqoshid merupakan komunitas hadrah yang berada di kampus Universitas Negeri Yogyakarta dengan tujuan utamanya berdakwah. Menggunakan musik hadrah tersebut komunitas ini mengajak para mahasiswa khususnya dan juga masyarakat umum untuk lebih dekat dengan Allah Swt dan Nabi Muhammad Saw.

Jika dianalisis menggunakan karakteristik spiritualitas yang dikemukakan oleh Delgado (Ardian, 2016:4), para anggota komunitas hadrah El-Maqoshid telah memenuhi karakteristik tersebut. 1) Spiritualitas memerlukan kepercayaan. Anggota El-Maqoshid meyakini bahwa dengan bersholawat mereka akan lebih dekat dengan Allah Swt dan Nabi Muhammad Saw, sehingga menimbulkan kedamaian dan ketenangan jiwa. 2) Spiritualitas melibatkan kondisi individu dalam pencarian makna dan tujuan, artinya ada sebuah misi yang hendak dicapai ketika bersholawat yaitu berdoa. 3) Spiritualitas meliputi kesadaran keterikatan baik itu dengan orang lain maupun dengan Tuhan. 
Seperti yang sudah dijelaskan sebelumnya bahwa banyak kegiatan El-Maqoshid yang mendatangkan jamaah, hal tersebut menunjukkan bahwa telah ada keterikatan antara jamaah/anggota dengan komunitas tersebut maupun dengan Allah Swt dan Nabi Muhammad Saw. 4) Spiritualitas adalah kepercayaan bahwa seseorang dapat melampaui batas dirinya dalam dimensi yang lebih tinggi. Hal ini erat kaitannya dengan kondisi jiwa seseorang, sholawat dipercayai dapat menjadi obat batiniah.

\section{Kesimpulan}

Komunitas hadrah El-Maqoshid menjadi salah satu wadah bagi mereka yang ingin mengenal lebih dalam syair-syair sholawat. Komunitas hadrah El-Maqoshid juga selalu berusaha menjadi jembatan bagi para anggotanya agar dapat berkomunikasi dengan Allah Swt dan Nabi Muhammad Saw melalui syair-syair sholawat. Namun, secara tidak disadari komunitas hadrah ElMaqoshid telah melakukan komodifikasi agama pada musik hadrah. Satu poin yang menjadi penting di sini bahwa komunitas hadrah El-Maqoshid melakukan komodifikasi tersebut untuk kepentingan bersama, untuk kesejahteraan anggotanya, serta tidak meninggalkan bahkan mengganti makna musik hadrah pada komunitas hadrah El-Maqoshid.

Semua bisyaroh yang didapat akan digunakan untuk mensejahterakan personil hadrah dan untuk kepentingan program kerja. Oleh karena itu tidak salah jika komunitas hadrah El-Maqoshid ini sangat bergantung pada pendapatan yang dihasilkan dari mereka tampil di berbagai acara. Meskipun demikian, komunitas hadrah El-Maqoshid ini tidak pernah mematok harga ketika mereka tampil, bahkan bisyaroh itu dianggapnya sebagai bonus atau hadiah setelah mereka tampil. Mereka masih mengedepankan tujuan utama yaitu untuk bersyiar dan berdakwah melalui musik hadrah.

Bentuk-bentuk komodifikasi yang ada pada komunitas hadrah El-Maqoshid diantaranya melalui eksistensi yang selalu digencarkan. Media sosial menjadi sasaran utama bagi komunitas ini, mengunggah foto maupun video ketika mereka latihan atau tampil merupakan salah satu cara yang dilakukan. Update terkait lagu-lagu sholawat juga terus dilakukan, kemudian juga melakukan rekaman yang dijadikan sebagai konten youtube. Melatih grup hadrah juga merupakan salah satu kegiatan El-Maqoshid yang mendapatkan keuntungan. Serta yang paling sering dilakukan yaitu menghadiri dan tampil di berbagai acara. Semua itu dilakukan oleh komunitas hadrah El-Maqoshid untuk kepentingan bersama.

Perkembangan serta kemajuan komunitas hadrah El-Maqoshid dari tahun ke tahun serta ada komodifikasi secara tidak langsung tersebut tidak mengubah makna 
dari musik hadrah. Mereka mempertahankan apa yang telah diajarkan oleh sesepuh mereka dengan menanamkan niat bermain hadrah adalah untuk syiar sholawat. Beberapa makna dan nilai spiritual yang terkandung dalam musik hadrah khususnya komunitas hadrah ElMaqoshid adalah ritual pemujaan, sarana bersyiar dan berdakwah, penyampai doa, dimaknai sebagai kekuatan jiwa, sebagai hiburan, serta menjadi sebuah eksistensi religius.

\section{Daftar Pustaka}

Afrianto, B. (2017). Musik Qosidah : dari Media Dakwah menjadi Hiburan. Skripsi S1.

Agger, B. (2006). Teori Sosial Kritis. Yogyakarta: Kreasi Wacana.

Ardian, I. (2016). Konsep Spiritualitas dan Religiusitas dalam Konteks Keperawatan Pasien Diabetes Melitus Tipe 2. Jurnal Keperawatan dan Pemikiran IImiah, 1-9.

Fridayanti. (2015). Religiusitas, Spiritualitas dalam Kajian Psikologi dan Urgensi Perumusan Religiusitas Islam. Jurnal IImiah Psikologi , 199-208

Larasati, N. O. (2015). Minat Spiritual Masyarakat Modern (Studi Kasus Masyarakat Penganut Kerohanian Sapta Darma di Daerah Istimewa Yogyakarta). Yogyakarta.

Miles, Matthew B. \& A. Michael Huberman. 2009. Analisis Data Kualitatif. Jakarta: UI-Press

Niaga, S. S. (2006). Fungsi dan Ciri Khas Kesenian Rebana di Pantura Jawa Tengah. Pengatahuan dan Pemikiran Seni

Nirwanto, B. (2015). Musik Hadroh Nurul Ikhwan di Kabupaten Pemalang. Seni Musik 4 .

Prasetyo, A. (2016). Aspek Spiritualitas sebagai Elemen Penting dalam Kesehatan. Jurnal Kesehatan AlMakna dan Nilai Spiritual Musik Hadrah pada Komunitas Hadrah El-Maqoshid | Arum Mei Nursyahida Dan Amika Wardana 